\title{
STRATEGI PROMOSI PRODUK KOPERASI JASA SYARIAH (KJKS) BAITUL MAAL WAT TAMWIL (BMT) JATI BARU PADANG
}

\author{
Yummil Hasan \\ Universitas Islam Negeri Imam Bonjol Padang \\ (E-mail: yummilhasan@gmail.com) \\ Nikmawati Sukri Ilahi \\ Universitas Islam Negeri Imam Bonjol Padang \\ (Email: nikmawati@gmail.com)
}

\begin{abstract}
To market a product, an institution or company must use a set of operational activities called the marketing mix. One of the marketing mixes used by KJKS BMT Jati Baru Padang is promotion, then we call it a promotion strategy. This promotion is intended to introduce and influence the community towards a product offered by KJKS BMT Jati Baru. Promotion strategy is one of the first in order to introduce products to consumers and this becomes very important because it deals with the benefits that will be obtained by the company. In this modern era BMT institutions are increasingly developing in the community. The development of these institutions encouraged BMT business to grow and resulted in this business competition becoming tight. For this reason, there is a need for this KJKS BMT Jati Baru promotion strategy in the face of competition, so that it can help market the product to increase the company's sales and customer development.

Keywords: Strategy, Promotion, Products, KJKS, BMT

Abstrak

Untuk memasarkan suatu produk, maka suatu lembaga atau perusahan harus menggunakan perangkat kegiatan operasional yang disebut bauran pemasaran. Salah satu bauran pemasaran yang digunakan KJKS BMT Jati Baru Padang adalah promosi, selanjutnya kita sebut strategi promosi. Promosi ini ditujukan untuk mengenalkan dan mempengaruhi masyarakat terhadap suatu produk yang ditawarkan KJKS BMT Jati Baru. Strategi promosi merupakan salah satu awal dalam rangka mengenalkan produk kepada konsumen dan ini menjadi sangat penting karena berhubungan dengan keuntungan-keuntungan yang akan diperoleh oleh perusahan. Dalam era modern ini lembaga BMT semakin berkembang di masyarakat. Perkembangan lembaga tersebut mendorong usaha BMT makin berkembang dan mengakibatkan persaingan bisnis ini menjadi ketat. Untuk itu perlu adanya strategi promosi KJKS BMT Jati Baru ini dalam menghadapi persaingan, sehingga dapat membantu memasarkan produk untuk meningkatkan penjualan perusahan dan perkembangan nasabah.

Kata Kunci: Strategi, Promosi, Produk, KJKS,BMT
\end{abstract}




\section{A. Pendahuluan}

Manusia sebagai makhluk individu memiliki berbagai keperluan hidup untuk mencukupi kebutuhan ekonominya. Untuk mencapai pemenuhan kebutuhan yang beragam tersebut maka tidak dapat diproduksi sendiri oleh individu yang bersangkutan. Dengan kata lain, ia harus bekerja sama dengan orang lain. Maka dari itu lembaga perekonomian sangat berperan penting untuk membantu masyarakat untuk memenuhi kebutuhannya. Menurut Kotler ${ }^{1}$ bauran pemasaran (marketing mix) adalah salah satu konsep utama dalam pemasaran modern yaitu merupakan perangkat variabel-variabel pemasaran terkontrol yang perusahan gabungkan untuk menghasilkan tanggapan yang diinginkannya dalam pasar sasaran. Tujuan pemasaran ini adalah untuk mengetahui dan memahami konsumen demikian baiknya sehingga produk atau jasa cocok bagi konsumen dan produk atau jasa itu bisa terjual dengan sendirinya. Karena marketing mix merupakan bagian dari seperangkat alat-alat pemasaran yang harus dimainkan untuk mendapatkan dampak maksimum terhadap pasar. Promosi merupakan salah satu variabel marketing mix yang digunakan oleh perusahan untuk melakukan komunikasi guna menyampaikan informasi, mempengaruhi, membujuk calon nasabah dan meningkatkan calon nasabah untuk tetap loyal terhadap produk yang ditawarkan.

Menurut Craven ${ }^{2}$ adapun komponen-komponen Strategi Promosi antar lain adalah berupa iklan (Advertising), penjualan perorangan (Personal Selling), promosi penjualan (Sales Promotion), dan publisitas (Publicity). Secara yuridis, masalah promosi telah diatur dalam undang-undang perlindungan konsumen tahun 1999. Dalam undang-undang ini, yang selanjutnya juga membahas tentang perbuatan yang dilarang bagi pelaku usaha dalam mempromosikan barang dan jasa. Mengingat di era globalisasi saat ini, dimana tingkat persaingan dibidang ekonomi sangat tinggi. Setiap perusahan baik itu di bidang barang maupun jasa dituntut untuk meningkatkan kualitas maupun kuantitasnya terhadap produk yang dihasilkan.

1 Philip Kotler, Dasar-Dasar Pemasaran, (Jakarta: PT Midas Surya Grafindo, 1987), h. 4

${ }_{2}$ David W. Craven, Pemasaran Strategis, (Jakarta: PT Gelora Aksara Pratama, 1996), h. 77 
Menurut Lubis ${ }^{3}$ dalam bidang kegiatan ekonomi, Islam memberikan pedoman-pedoman atau aturan-aturan hukum, yang pada umumnya dalam bentuk garis besar. Hal itu dimaksudkan untuk memberi peluang bagi perkembangan kegiatan perekonomian di kemudian hari. Dalam hal ini ekonomi yang tidak luput dari kajian islam bertujuan menuntun agar manusia berada di jalan lurus. Kegiatan ekonomi dalam pandangan Islam merupakan tuntunan kehidupan dan anjuran yang memiliki dimensi ibadah.

Sementara itu Soemitra ${ }^{4}$ menjelaskan, sebagai lembaga ekonomi yang berbasis syariah, Koperasi Jasa Keuangan Syariah (KJKS) Baitul Maal Wat Tamwil (BMT) berupaya untuk mewujudkan tujuannya yaitu meningkatkan kualitas usaha ekonomi untuk kesejahteraan anggota khususnya dan masyarakat pada umumnya. Dalam melaksanakan kegiatannya Koperasi Jasa Keuangan Syariah (KJKS) Baitul Maal Wat Tamwil (BMT) mengembangkan usaha-usaha produktif dan investasi dalam meningkatkan kualitas kegiatan ekonomi pengusaha makro dan kecil, antara lain mendorong kegiatan menabung dan pembiayaan kegiatan ekonominya.

Dari pengamatan yang dilakukan dalam pelaksanaan promosi yang dilakukan Koperasi Jasa Keuangan Syariah (KJKS) Baitul Maal Wat Tamwil (BMT) Jati Baru ini belum menerapkan strategi promosi secara keseluruhan, baik itu dari segi periklanan (Advertising), penjualan langsung (personal selling), promosi penjualan (sales promotion), dan publisitas (publicity). Sehingga masih ada masyarakat yang belum mengenal kegunaan dan Memahami tujuan dari Koperasi Jasa Keuangan Syariah (KJKS) Baitul Maal Wat Tamwil (BMT) tersebut. Penulis mengamati bahwa dalam penggunaan promosi iklan melalui media brosur tidak ditemukan dilembaga KJKS BMT Jati Baru, untuk meyakini kembali penulis mendatangi dan mengamati lagi, namun penulis tidak dapat menemukan brosur tersebut di KJKS BMT. Saat penulis menanyakan brosur pada manajer, diungkapkan bahwa bahwa brosur tersebut telah habis dan belum dilakukan pencetakan ulang. Hal diatas secara tidak langsung membuat nasabah tidak mengetahui produk yang ditawarkan KJKS BMT Jati Baru. sehingga

${ }^{3}$ Suhrawardi Lubis, Hukum ekonomi Islam, (Jakarta: Sinar Grafika, 2012), h. 4

4 Andi Soemitra, Bank dan Lembaga Keuangan Syariah, (Jakarta: Kencana Prenada Media Group, 2009), h. 452 
dikhawatirkan akan berakibat jumlah nasabah tidak bertambah. Apabila produk kurang dikenal oleh konsumen maka usaha tersebut berdampak tidak akan mengalami peningkatan.

\section{B. Landasan Teoritis}

\section{Konsep Promosi}

Pemasaran pada dasarnya mencakup segala kegiatan seperti pembujukan, promosi, publikasi. Namun begitu, pemasaran bukanlah semata-mata kegiatan seperti menjual dan mempromosikan sesuatu. Pemasaran adalah suatu konsep yang menyangkut suatu sikap mental, suatu cara berpikir untuk melakukan suatu penjualan. Dalam pemasaran jasa, pelanggan lebih sulit membayangkan dan membangun keinginan untuk memiliki. Hal ini disebabkan oleh karakteristik jasa yang tidak berwujud. Persepsi pelanggan terhadap risiko cenderung tinggi karena jasa tidak bisa disentuh, dibau, dirasa, atau dicoba sebelum dibeli. Kualitas jasa cenderung ditentukan oleh pengalaman dan ini bisa dirasakan setelah pelanggan membeli dan mengkonsumsi sekaligus memproduksi secara bersamaan. Seorang pemasar jasa dapat memciptakan kesadaran pelanggan akan produk dan mengujicobakan produk sebelum penjualan, tetapi mereka menunjukkan manfaat dan membangun prefensi produk paling efektif setelah penjualan Hakim. ${ }^{5}$

Sementara itu Kasmir ${ }^{6}$ menjelaskan promosi produk yang dihasilkan oleh perusahan merupakan salah satu fungsi yang penting dalam pemasaran. Aktivitas promosi merupakan aktivitas kreatif yang harus dikendalikan secara efisien dan efektif. Promosi merupakan kegiatan marketing mix yang terakhir. Dalam kegiatan ini setiap perusahan berusaha untuk mempromosikan seluruh produk dan jasa yang dimilikinya baik secara langsung maupun tidak langsung. Promosi merupakan sarana yang paling ampuh untuk menarik dan mempertahankan nasabahnya. Salah satu tujuan promosi adalah menginformasikan segala jenis produk yang ditawarkan dan berusaha menarik calon nasabah yang baru.

Michael Ray, mendefinisikan promosi sebagai koordinasi dari seluruh upaya yang dimulai pihak penjual untuk membangun berbagai saluran informasi

5 Hakim, Arman, Nasution dkk, Manajemen Pemasaran untuk Engineering, (Yogyakarta: CV Andi Offset, 2006), h. 15 224

${ }^{6}$ Kasmir, Manajemen Perbankan, (Jakarta: PT Raja Grafindo Persada, 2010), h. 
dan persuasi untuk menjual barang dan jasa atau memperkenalkan suatu gagasan. Walaupun komunikasi antara perusahan dan konsumen secara implicit berlangsung pada setiap unsur atau bagian dari marketing mix sebagaimana yang telah dijelaskan sebelumnya, namun sebagian besar komunikasi perusahan berlangsung sebagai bagian baru suatu program promosi yang diawasi dan direncanakan dengan hati-hati. Menurut Morrisan ${ }^{7}$ instrument dasar yang digunakan untuk mencapai tujuan komunikasi perusahan disebut dengan bauran promosi atau promotional mix.

Purnama $^{8}$ mengatakan bahwa berkomunikasi dengan para pembeli sudah mereka membeli suatu produk adalah suatu kegiatan promosi penting. Kunjungan ulang para wiraniaga, iklan-iklan yang menekankan kemampuan pelayanan suatu perusahan, dorongan yang diberikan kepada pemakai untuk mencari informasi atau melaporkan masalah-masalah.

\section{Strategi Promosi}

Strategi promosi merupakan salah satu awal dalam rangka mengenalkan produk kepada konsumen dan ini menjadi sangat penting karena berhubungan dengan keuntungan-keuntungan yang akan diperoleh oleh perusahan. Strategi promosi akan bisa berguna dengan optimal bila didukung dengan perencanaan yang terstruktur dengan baik. Strategi promosi adalah sebuah program terkendali dan terpadu dari metode komunikasi dan material yang dirancang untuk menghadirkan perusahan dan produk-produknya kepada calon konsumen. ${ }^{9}$

Perusahan jasa harus dapat merancang strategi promosi yang tepat dalam mencapai tujuan perusahan adalah dapat menarik minat konsumen untuk menggunakan jasa yang ditawarkan. Oleh karena itu untuk menarik perhatian melakukan pembelian maka perusahan harus bisa menerapkan suatu strategi pemasaran yang tepat sesuai dengan kondisi pasar yang dihadapi. Karena sebaik apapun bentuk sebuah produk dan seberapa besar manfaatnya, jika tidak ada orang yang mengetahui keberadaannya, maka mustahil produk tersebut digunakan

7 Morrisan, Periklanan Komunikasi Pemasaran Terpadu, (Jakarta: Kencana Prenada Media Group, 2010), h. 16

${ }^{8}$ C.M Lingga Purnama, Strategic Marketing Plan, (Jakarta: Gramedia Pustaka Utama, 2001), h. 151.

9 Harper W Boyd, Manajemen Pemasaran, suatu Pendekatan Strategis dengan Orienatsi Global, (Jakarta: Erlangga, 2000), h. 65. 
konsumen atau nasabah. Sarana dan prasarana yang dibutuhkan secara efektif agar informasi mengenai hadirnya produk dapat sampai kepada masyarakat merupakan upaya awal dari kegiatan promosi.

Menurut Swastha ${ }^{10}$ strategi promosi adalah perencanaan kegiatan komunikasi informal dari produsen kepada konsumen untuk mempengaruhi sikap dan perilaku, baik individu ataupun organisasi terlebih dahulu dalam melakukan kegiatan diperlukan suatu rencana yang matang, karena merupakan proses dasar yang dipergunakan untuk memilih tujuan dan menentukan bagaimana cara mencapai tujuan tersebut sebelum dapat mengorganisasikan, memimpin, mengendalikan terlebih dahulu. Suatu perusahan harus membuat rencana yang memberikan tujuan dan arahan kepada organiasasi, menentukan apa yang dikerjakan, bagaimana mengerjakannya, dan siapa yang mengerjakannya. Promotional mix adalah kombinasi strategi yang paling baik dari variabel-variabel promosi yang semuanya direncanakan untuk mencapai tujuan program penjualan.

Dalam hal ini akan dibahas secara rinci tentang komponen-komponen Strategi Promosi berupa periklanan (advertising), penjualan perorangan (personal selling), promosi penjualan (sales promotion), dan publisitas (publicity) sebagai berikut:

\section{a. Iklan (advertising)}

Sebuah iklan umumnya dimaksudkan untuk meningkatkan citra dari merek, lembaga, atau industri tertentu. Faktor utama periklanan adalah bahwa iklan harus menggugah perhatian calon konsumen terhadap produk atau jasa yang ditawarkan perusahan. Para konsumen potensial dibuat untuk memerhatikan dan peduli terhadap produk yang memberikan manfaat bagi mereka yang akan memberikan alasan bagi mereka untuk membeli. Periklanan dapat menghubungkan konsumen yang sudah ada dan mengingatkan mereka akan alasan dalam memilih produk yang diiklankan. Konsumen yang sudah ada juga dibuat untuk tetap menjaga hubungan dengan produk dan jasa terbaru yang tersedia bagi mereka, dengan mengingatkan keberadaan produk secara insentif.

${ }^{10}$ Basu Swastha dan Irwan, Manajemen Pemasaran Modern, (Yogyakarta: Liberty, 2005), h. 351. 
Periklanan memberikan perusahan kesempatan untuk mengembangkan satu merek dan satu identitas. ${ }^{11}$

Iklan adalah setiap bentuk presentasi dan promosi ide, barang, atau jasa oleh sponsor tertentu. Periklanan dipandang sebagai kegiatan penawaran kepada suatu kelompok masyarakat baik secara langsung lisan maupun dengan penglihatan (berupa berita) tentang suatu produk, jasa atau ide. ${ }^{12}$ Menurut Jeff Madura, iklan adalah presentasi penjualan yang bersifat nonpersonal yang dikomunikasikan dalam bentuk media atau nonmedia dengan tujuan untuk memengaruhi sejumlah besar pelanggan. ${ }^{13}$ Kegiatan periklanan berarti kegiatan menyebarluaskan berita (informasi) kepada pasar (masyarakat atau konsumen). ${ }^{14}$

\section{b. Penjualan Langsung (personal selling)}

Penjualan langsung adalah presentasi langsung dalam suatu percakapan dengan satu atau lebih calon pembeli dengan maksud untuk mendapatkan penjualan. Personal selling atau penjualan perorangan adalah suatu bentuk interaksi langsung dengan satu calon pembeli atau lebih untuk melakukan presentasi, menjawab pertanyaan, dan menerima pesanan. ${ }^{15}$

Penjualan personal (personal selling) menurut Philip Kotler adalah potensi lisan dalam pembicaraan dengan salah satu pembeli untuk tujuan melakukan penjualan. ${ }^{16}$ Dari beberapa definisi tersebut maka dapat dikatakan penjualan perorangan (personal selling) merupakan kegiatan yang dilakukan perorangan dengan tujuan mempengaruhi konsumen sehingga dapat memperoleh penjualan. Penjualan perorangan membutuhkan usaha pribadi untuk memengaruhi permintaan seorang pelanggan akan suatu produk.

Dalam hal ini, penjual berupaya untuk membantu atau membujuk calon pembeli untuk membeli produk yang ditawarkan. Komunikasi yang bersifat individual dan personal dalam penjualan personal ini memungkinkan pihak penjual menyesuaikan pesan berdasarkan kebutuhan khusus atau situasi khusus

${ }^{11}$ Agus Hermawan, Komunikasi Pemasaran, (Malang: PT. Gelora Aksara Pratama, 2012), h. 72

${ }_{12}$ David W. Craven, Pemasaran Strategis..., h. 77

13 Jeff Madura, Pengantar Bisnis, (Jakarta: Salemba Empat, 2007), h. 274.

${ }_{14}^{14}$ M. Mursid, Manajemen Pemasaran, (Jakarta: PT Bumi Aksara, 2014), h. 96

${ }_{16}^{15}$ C.M Lingga Purnama, Strategic Marketing Plan..., h. 166.

16 Buchari Alma, Manajemen Pemasaran dan Pemasaran Jasa, (Bandung: Penerbit Alfabeta, 2011), h. 177 
calon pembeli. Penjualan personal ini memungkinkan terjadinya umpan balik secara langsung dan lebih tepat karena dampak dari presentasi penjualan yang dilakukan dapat dinilai dari reaksi calon pembeli atau pelanggan. ${ }^{17}$ Hal utama yang dipersiapkan dalam kegiatan penjualan personal sebagai bagian metode pemasaran adalah insentif yang diberikan kepada tenaga penjual yang layak berdasarkan keterampilan yang dimilikinya atas kemampuan "membujuk" calon konsumen untuk membeli.

Prinsip-prinsip dasar penjualan perorangan (personal selling) adalah:

1) Persiapan yang matang, meliputi pengetahuan:

a) Mengenal pasar dimana barang akan dijual yaitu meliputi keteranganketerangan mengenai keadaan perekonomian pada umumnya, persaingan trend harga dan sebagainya.

b) Mengenal langganan dan calon langganan. Dalam hal ini perlu diketahui buying motives (motif orang membeli) dan buying habits (kebiasaan orang membeli).

c) Cukup mengetahui tentang produk yang akan dijual.

d) Prinsip dasar harus dikuasai oleh penjual karena dengan demikian ia dapat mempengaruhi konsumen untuk membuat transaksi yang menguntungkan kedua belah pihak.

2) Mendapatkan atau menentukan tempat pembeli

Dalam mendapatkan pembeli seorang penjual harus berpedoman kepada kebijaksanaan perusahan mengenai channel of distribution yang dipergunakan.

3) Merealisasikan penjualan

Meskipun dimana terjadinya penjualan tersebut beraneka ragam, tetapi langkah-langkah yang diambil oleh penjual dalam proses penjualan adalah :

(a) Pendekatan dan pemberian hormat; (b) Penentuan kebutuhan langganan;

(c) Menyajikan barang dengan efektif; (d) Mengatasi keberatan-keberatan; (e) Melaksanakan penjualan-penjualan.

4) Menimbulkan goodwill setelah penjualan terjadi.

\footnotetext{
${ }^{17}$ Morrisan, Periklanan Komunikasi Pemasaran Terpadu..., h. 34
} 
Jika penjualan terjadi dengan baik, maka pembeli akan memperoleh barang sesuai dengan yang diinginkan, dan penjual memperoleh laba. Hal ini akan mempunyai pengaruh baik terhadap pembeli tersebut, yaitu akan membeli lagi kepada penjual yang sama dikemudian hari. ${ }^{18}$

Penjualan personal (wiraniaga) mempunyai peranan yang penting dalam pemasaran produk atau jasa, karena : (1) Interaksi secara personal antar penyedia jasa dan konsumen sangat penting; (2) Jasa tersebut disediakan oleh orang bukan oleh mesin; (3) Orang merupakan bagian dari produk jasa.

Sedangkan Hermawan ${ }^{19}$ menjelaskan aktivitas penjualan personal memiliki beberapa fungsi yaitu : (1) Mencari prospek (Prospecting), yaitu mencari pembeli dan menjalin hubungan dengan mereka; (2) Menetapkan sasaran (Targeting), yaitu menentukan pelanggan yang akan dituju; (3) Mengkomunikasikan (Communicating), yaitu memberi informasi mengenai produk kepada pelanggan; (4) Menjual (Selling), yaitu mendekati, mempresentasikan dan mendemonstrasikan, mengatasi penolakan, serta menjual produk kepada pelanggan; (5) Melayani (Servicing), yaitu memberikan berbagai jasa dan pelayanan kepada pelanggan; (6) Mengumpulkan informasi (Information gathering), yaitu melakukan riset dan intelijen pasar; (7) Mengalokasikan (Allocating), yaitu mengalokasikan kelangkaan waktu penjual demi pembeli.

Menurut Madura $^{20}$ menjelaskan salah satu kunci dari kesuksesan penjualan dalam jangka panjang adalah perhatian yang diberikan kepada pembeli setelah penjualan dilakukan. Usaha ini meningkatkan kredibilitas tenaga penjualan dan mendorong pelanggan yang ada untuk menghubungi kembali ketika mereka membutuhkan tambahan produk. Tenaga penjualan seharusnya juga menindaklanjuti calon-calon pelanggan yang tidak membeli produk setelah presentasi penjualan. Calon-calon pelanggan ini dapat mengalami perubahan anggaran dan menjadi lebih berminat untuk membeli produk dibelakangan hari.

\section{c. Promosi penjualan (sales promotion)}

\footnotetext{
${ }^{18}$ Buchari Alma, Manajemen Pemasaran dan Pemasaran Jasa..., h. 186

${ }^{19}$ Hermawan, Agus, komunikasi pemasaran..., h. 109

20 Jeff Madura, Pengantar Bisnis..., h. 284
} 
Promosi penjualan (sales promotion) adalah Keinginan menawarkan insentif dalam periode tertentu untuk mendorong keinginan calon konsumen, para penjual atau perantara. $^{21}$ Yang dilakukan dengan peragaan, pertunjukkan, pameran, dan berbagai macam usaha penjualan yang tidak bersifat rutin. Menurut Agus Hermawan dalam buku komunikasi pemasaran mengatakan, promosi penjualan adalah bentuk persuasi langsung melalui penggunaan berbagai insentif yang dapat diatur untuk merangsang pembelian produk dengan segera atau meningkatkan jumlah barang yang dibeli pelanggan. ${ }^{22}$

Promosi penjualan menurut Philip Kotler adalah bahan inti dalam kampanye pemasaran yang terdiri dari koleksi alat insentif yang dirancang untuk menstimulasi pembelian yang lebih erat atau lebih besar atas produk atau jasa tertentu oleh konsumen atau perdagangan. ${ }^{23}$ Promosi penjualan merupakan promosi yang digunakan untuk meningkatkan penjualan melalui potongan harga atau hadiah pada waktu tertentu terhadap barang tertentu.

Maka dari beberapa pengertian diatas dapat diartikan promosi penjualan adalah suatu cara yang dilakukan penjual melalui cara-cara tertentu dalam mempengaruhi konsumen sehingga konsumen tertarik dan dapat menghasilkan penjualan. Melalui promosi penjualan dapat menarik pelanggan baru, memengaruhi pelanggannya untuk mencoba produk baru, mendorong pelanggan membeli lebih banyak, menyerang aktivitas promosi pesaing, meningkatkan impulse buying (pembelian tanpa rencana sebelumnya), atau mengupayakan kerja sama yang lebih erat dengan pengecer.

Secara umum tujuan-tujuan dari promosi penjualan dapat digeneralisasikan menjadi tiga, yaitu: meningkatkan permintaan dari para pengguna industri atau konsumen akhir, meningkatkan kinerja bisnis, dan mendukung atau mengoordinasikan kegiatan penjualan personal dan iklan. ${ }^{24}$

Alat promosi penjualan sangat beragam, semuanya memberikan tiga manfaat yang berbeda antara lain komunikasi, insentif, dan ajakan. Untuk lebih rincinya akan dijelaskan sebagai berikut :

${ }^{21}$ Craven, David W, Pemasaran Strategis..., h. 77

${ }^{22}$ Hermawan, Agus, komunikasi pemasaran..., h. 109

${ }^{23}$ Philip Kotler, Manajemen Pemasaran, (Jakarta: Erlangga, 2008), h. 219.

${ }^{24}$ Hermawan, Agus, komunikasi pemasaran..., h. 122 
1) Komunikasi; Promosi penjualan menarik perhatian dan biasanya memberikan informasi yang dapat mengarahkan konsumen kepada produk.

2) Insentif; Promosi penjualan menggabungkan sejumlah kebebasan, dorongan, atau kontribusi yang memberi nilai bagi konsumen.

3) Ajakan; Promosi penjualan merupakan ajakan untuk melakukan transaksi pembelian sekarang. ${ }^{25}$ Keuntungan lain dari promosi penjualan adalah bersifat responsif terhadap peristiwa-peristiwa khusus. Dalam banyak kesempatan, promosi penjualan lebih mendukung upaya-upaya promosi yang dapat mengurangi kesetian jangka panjang karena konsumen cenderung lebih menggantungkan diri pada promosi khusus. Dalam menggunakan promosi penjualan, suatu perusahan harus menetapkan tujuan, memilih kiatnya, mengembangkan program, menguji program itu lebih dahulu, menerapkan dan mengendalikannya, serta menilai hasilnya.

Untuk lebih rinci akan dijelaskan sebagai berikut :

1) Menetapkan tujuan promosi penjualan

Tujuan promosi penjualan diperoleh atau diturunkan dari tujuan promosi yang lebih luas, tujuan promosi diturunkan dari tujuan pemasaran yang lebih mendasar yang dikembangkan untuk produk tersebut. Berikut Tujuan promosi penjualan digunakan (sales promotion) ialah: a) Menarik pembeli baru; b) Memberi hadiah atau penghargaan kepada konsumen-konsumen atau langganan lama; c) Meningkatkan daya pembelian ulang dari konsumen lama; d) Menghindarkan konsumen lari ke kerek lain; e) Mempopulerkan merek atau meningkatkan loyalitas.

Meningkatkan volume penjualan jangka pendek dalam rangka memperluas "market share" jangka panjang. ${ }^{26}$

2) Memilih kiat promosi penjualan

Dalam memilih kiat promosi penjualan, perlu diperhatikan tiga hal penting yaitu kiat promosi konsumen, kiat promosi perdagangan, dan kiat promosi bisnis dan wiraniaga.

3) Pra-uji program promosi penjualan

${ }^{25}$ C.M Lingga Purnama, Strategic Marketing Plan..., h. 172

${ }^{26}$ Buchari Alma, Manajemen Pemasaran dan Pemasaran Jasa..., h. 188 
Walaupun sebagian besar program promosi penjualan dirancang berdasarkan pengalaman, pra-uji harus dilakukan untuk menentukan apakah kiatnya tepat, ukuran insentifnya, dan metode penyajiannya efisien.

4) Menerapkan dan mengendalikan program promosi penjualan

Manajer pemasaran harus mempersiapkan rencana penerapan dan pengendalian untuk tiap promosi yang mencakup lead time yaitu waktu yang diperlukan untuk menyiapkan program sebelum meluncurkannya, lead time ini mencakup perencanaan awal, rancangan, dan persetujuan paket modifikasi atau materi yang akan didistribusikan dan sell time yaitu dimulai dengan peluncuran promosi dan berakhir ketika hamper barang dagangan promosi berada ditangan konsumen.

5) Mengevaluasi hasil promosi penjualan

Evaluasi hasil promosi sangat penting untuk mengetahui sejauh mana efektivitas promosi dan sejauh mana tujuan telah dicapai. Hal ini perlu dilakukan secara berkesinambungan agar control terhadap promosi yang dilakukan dapat dilakukan. $^{27}$

Karena beragamnya insentif, penetapan harga, dan kemampuan komunikasi. Promosi penjualan cukup fleksibel untuk mencapai berbagai tujuan pemasaran. Seorang manajer produk dapat menargetkan pembeli, perantara, dan wiraniaga dan dapat mengukur tanggapan penjualan dari kegiatan-kegiatan promosi penjualan untuk menentukan keefektifan mereka.Kendati demikian, promosi penjualan bukan tanpa kelemahan. Dalam banyak kesempatan, promosi penjualan lebih mendukung upaya-upaya promosi lainnya ketimbang menggantikan periklanan dan penjualan perorangan. Pengendalian perlu dilakukan untuk mencegah orang-orang tertentu untuk tidak mengambil keuntungan dari penawaran bebas, kupon, dan insentif lainnya.

\section{d. Publisitas ( Publicity )}

Publisitas (publicity) adalah suatu cara merangsang timbulnya permintaan yang bersifat impersonal terhadap suatu produk, jasa, atau ide dengan cara

\footnotetext{
${ }^{27}$ C.M Lingga Purnama, Strategic Marketing Plan..., h. 173
} 
memasang berita komersial di mass media dan tidak dibayar langsung oleh suatu sponsor. $^{28}$

Sejumlah informasi tentang seseorang, barang, organisasi atau perusahan yang disebarluaskan ke masyarakat dengan cara membuat berita yang mempunyai arti komersial atau berupa penyajian-penyajian yang lain yang bersifat positif. Dengan demikian suatu perusahan beserta produknya dapat menjadi perhatian umum. Publisitas merupakan pemanfaatan nilai - nilai berita yang terkandung dalam suatu produk untuk membentuk citra produk yang bersangkutan. Dibandingkan dengan iklan, publisitas mempunyai kredibilitas yang lebih baik, karena pembenaran (baik langsung maupun tidak langsung) dilakukan oleh pihak lain selain pemilik iklan. Di samping itu karena publisitas dimasukkan dalam berita atau artikel koran, tabloid, majalah, radio dan televisi maka khalayak tidak memandangnya sebagai komunikasi promosi. Kegiatan-kegiatan hubungan masyarakat dapat memberikan kontribusi yang penting bagi strategi promosi jika kegiatan-kegiatan tersebut direncanakan dan dilakukan untuk mencapai tujuantujuan promosi tertentu. Hubungan masyarakat juga digunakan untuk tujuantujuan organisasi seperti komunikasi dengan para analisis keuangan. Publisitas bisa bersifat negatif atau positif dan sampai batas tertentu tidak dapat dikendalikan seperti komponen-komponen promosi lainnya. Karena organisasi tidak membeli liputan media, maka publisitas merupakan cara berkomunikasi yang relative murah. Media umumnya menyukai topic-topik yang diminati masyarakat.

Dari beberapa definisi diatas dapat dikatakan bahwa publisitas (publicity) merupakan informasi yang disampaikan pada masyarakat untuk menciptakan kesan menarik bagi perusahan tanpa mengeluarkan biaya. Publisitas dapat memberi informasi lebih banyak dan lebih terperinci daripada iklan. Namun demikian karena tidak ada hubungan perjanjian antara pihak yang diuntungkan dan pihak penyaji, maka pihak yang diuntungkan tidak dapat mengatur kapan publisitas itu akan disajikan atau bagaimana publisitas tersebut disajikan. Oleh

${ }^{28}$ Craven, David W, Pemasaran Strategis..., h. 77 
karena itu, kini publisitas biasanya merupakan bagian dari departemen humas perusahaan. $^{29}$

Menurut Purnama daya tarik publisitas didasarkan pada tiga sifat khusus, yaitu : (1) Kredibilitas yang tinggi, yaitu Berita dan gambar lebih orientik dan dapat dipercaya oleh pembaca; (2) Kemampuan menangkap pembeli yang tidak menduga, hubungan masyarakat dapat menjangkau banyak calon pembeli yang cenderung menghindari wiraniaga dan iklan. Pesan diterima oleh pembeli lebih sebagai berita, bukan sebagai komunikasi dengan tujuan penjualan; (3) Dramatisasi, seperti halnya periklanan, publisitas atau hubungan masyarakat memiliki kemampuan untuk mendramatisasi suatu perusahan atau produk. ${ }^{30}$

Keuntungan publisitas terletak pada efisiensi biaya karena perusahan tidak membayar media masa sebagai sarana promosi tersebut. Namun demikian, publisitas yang bersifat negatif dapat menimbulkan dampak buruk bagi perusahan. Selain itu, bentuk promosi ini tidak dapat dikontrol seperti komponen promosi lainnya.

\section{Pembahasan: Koperasi Jasa Keuangan Syariah (KJKS) Baitul Maal Wat Tamwil (BMT)}

BMT sebagai lembaga keuangan syariah dengan system bagi hasil dirancang untuk terbinanya kebersamaan dalam menanggung resiko usaha dan berbagi hasil usaha antara pemilik dana (Rab Al-Maal) yang menyimpan uangnyadi BMT, BMT selaku pengelola dana (mudharib), dan masyarakat yang mmbutuhkan dana yang bisa berstatus peminjam dana atau pengelola usaha. ${ }^{31}$ Pembangunan keuangan diarahkan pada peningkatan kemampuan dan daya guna keseluruhan tatanan, perangkat, kelembagaan, dan kebijaksanaan keuangan dalam menunjang kesinambungan pembangunan dan peningkatan kemandirian bangsa melalui peningkatan kemampuan keuangan yang makin andal, efisien, dan mampu memenuhi tuntutan pembangunan, penciptaan suasana yang mendorong tumbuhnya inisiatif dan kreativitas masyarakat, serta meluasnya peran serta

\footnotetext{
${ }^{29}$ Fandy Tjiptono, Pemasaran Jasa dan Kualitas Pelayanan, (Malang: Bayumedia Publishing, 2007), h. 228

${ }_{30}$ C.M Lingga Purnama, Strategic Marketing Plan..., h. 177

${ }^{31}$ Syukri Iska dan Rizal, Lembaga Keuangan Syari'ah, (Batusangkar: Batusangkar Press, 2005), h. 85
} 
masyarakat dalam pembangunan dan melalui upaya untuk terus meningkatkan tabungan nasional sebagai sumber utama pembiayaan pembangunan.

Seiring dengan itu, maka berbagai lembaga keuangan baik bank maupun bukan bank mulai tumbuh berkembangan secara marak di Negara kita. Baik lembaga yang dikelola secara formal maupun informal. Berkaitan dengan bentuk dan struktur lembaga keuangan non bank, telah lahir lembaga keuangan islami yang mendasarkan prinsip kerjanya berdasarkan syariah islam, yaitu disebut dengan Baitul Maal Wat Tamwil (BMT). BMT adalah lembaga pendukung peningkatan kualitas usaha ekonomi pengusaha mikro dan pengusaha kecil bawah berlandaskan sistem syariah. Baitul maal wat tamwil (BMT) adalah suatu lembaga ekonomi rakyat kecil yang berupaya mengembangkan usaha-usaha produktif dan investasi dalam meningkatkan kegiatan ekonomi pengusaha kecil berdasarkan prinsip syariah dan prinsip koperasi. Baitul maal wat tamwil merupakan sebuah sarana pengelolaan dana dari ummat, oleh ummat, dan untuk ummat yang bebas dari riba.

Baitul maal wat tamwil (BMT) hadir sebagai wahana transformasi ekonomi dari para aghniya (pemilik uang) kepada dhu'afa, pedagang kecil yang membutuhkan modal usaha. BMT juga merupakan kembaga keuangan syariah yang menerima dan mendistribusikan dana islam yang berupa zakat, infaq, shadaqah, hibah dan wakaf yang dipercayakan kepadanya untuk disalurkan kepada yang berhak. BMT dibangun dengan basis keummatan, karena dibentuk dari, oleh, dan untuk masyarakat. Solusi pemberdayaan usaha kecil dan menengah. Landasan hokum cukup kuat (UU No. 7/1992, UU No. 10/1998), menyelenggarakan kegiatan usaha pelayanan dan jasa keuangan dalam skala kecil dan menengah. UU No. 10/1998, pasal 6, lembaga keuangan konvensional dapat menyelenggarakan unit pelayanan syaria'ah seperti bank syariah dengan menggunakan prinsip bagi hasil (Profit and Loss Sharing) secara dual banking system. $^{32}$

BMT didirikan dengan berasaskan pada masyarakat yang salaam, yaitu penuh keselamatan, kedamaian, dan kesejahteraan. Prinsip dasar BMT, adalah :

${ }^{32}$ Ahmad Rodoni, Lembaga Keuangan Syariah, (Jakarta: PT. Bestari Buana Murni, 2008), h. 69 
1) Ahsan (mutu hasil kerja terbaik), thayyiban (terindah), ahsanu'amala (memuaskan semua pihak), dan sesuai dengan nilai-nilai salaam: keselamatan, kedamaian, dan kesejahteraan.

2) Barokah, artinya berdaya guna, berhasil guna, adanya penguatan jaringan, transparan (keterbukaan), dan bertanggung jawab sepenuhnya kepada masyarakat.

3) Spiritual communication (penguatan nilai ruhiyah)

4) Demokratis, partisipatif, dan inklusif.

Prinsip-Prinsip utama BMT, yaitu : (1) Keimanan dan ketakwaan pada Allah SWT dengan mengimplentasikan prinsip-prinsip syariah dan muamalah islam kedalam kehidupan nyata; (2) Keterpaduan (kaffah) dimana nilai-nilai spiritual berfungsi mengarahkan dan menggerakkan etika dan moral yang dinamis, proaktif, progresif, adil, dan berakhlak mulia; (3)Kekeluargaan; (4) Kebersamaan; (5) Kemandirian; (6) Profesionalisme; (7) Istikamah, konsisten, berkelanjutan tanpa henti dan tidak pernah putus asa. ${ }^{33}$

Dalam melaksanakan kegiatan operasionalnya, yakni melayani masyarakat, kegiatan produk-produk KJKS BMT meliputi dua kegiatan, yaitu simpanan mudharabah dan pembiayaan.

1) Simpanan mudharabah

Simpanan mudharabah adalah simpanan yang dilakukan oleh pemilik dana atau anggota, yang selanjutnya akan mendapatkan bagi hasil sesuai dengan kesepakatan di muka berdasarkan presenatse pendapatan (nisbah). Simpanan mudharabah terdiri dari beberapa macam bentuk simpanan, yaitu : (a) Simpanan pendidikan, simpanan dana pendidikan yang dapat disetor sewaktu-waktu, diambil manakala akan melanjutkan sekolah atau pendidikan; (b) Simpanan hari raya, simpanan untuk persiapan hari raya yang dapat disetor sewaktu-waktu dan diambil 10 hari sebelum hari raya; (c) Simpanan aqiqah, simpanan untuk persiapan berqurban dan aqiqah yang dapat disetor sewaktu-waktu dan diambil 10 hari sebelum idul qurban; (d) Simpanan walimah, simpanan yang dipersiapkan untuk mengadakan kegiatan walimah, baik khitanan, nikah, tasmiyah dan walimah

${ }^{33}$ Andi Soemitra, Bank dan Lembaga Keuangan Syariah..., h. 453 
lainnya; (e) Simpanan ziarah, simpanan dari anggota atau nasabah yang berencana melaksanakan ziarah ke Baitullah (ibadah haji) di makkah al mukarramah atau melaksanakan ibadah umrah; (e) Simpanan wadi'ah, Titipan atau amanah dari pemilik dana kepada BMT, dimana BMT sebagai penerima amanat wajib menjaga keutuhannya dan keselamatan dana yang dititipkan dan tidak mendapatkan bagi hasil karena sifatnya hanyalah titipan biasa (amanat). Akad wadi'ah (titipan tidak berbagi hasil), diantaranya :

Simpanan yad al-amanah; titipan dana zakat, infak dan sedekah untuk disampaikan kepada yang berhak. Simpanan yad ad-damanah; giro yang sewaktuwaktu dapat diambil oleh penyimpan. ${ }^{34}$

\section{2) Pembiayaan}

Pembiayaan adalah kegiatan BMT dalam hal menyalurkan dana kepada ummat melalui pinjaman untuk keperluan menjalankan usaha yang ditekuni oleh nasabah atau anggota sesuai dengan prosedur dan ketentuan yang berlaku serta kesepakatan bersama. Produk pembiayaan terbagi dalam beberapa macam, yaitu :

a) Mudharabah, suatu perjanjian antara pemilik dana BMT (Shahibul Maal) dengan pengelola dana anggota (Mudharib) yang keuntungannya dibagi menurut rasio/nisbah yang telah disepakati bersama di muka. Bila terjadi kerugian, maka shahibul maal menanggung kerugian dana, sedangkan mudharib menanggung kerugian pelayanan material dan kehilangan imbalan kerja.

b) Musyarakah, perjanjian kerjasama antara anggota dengan BMT dimana modal dari kedua belah pihak digabungkan untuk usaha tertentu yang akan dijalankan oleh anggota. Keuntungan dan kerugian ditanggung bersama sesuai kesepakatan di muka.

c) Bai bitsman ajil, prosese jual beli di mana BMT menalangi terlebih dahulu kepada anggota dalam pembelian suatu barang tertentu yang dibutuhkan. Kemudian anggota akan membayar harga dasar barang dan keuntungan yang disepakati bersama kepada BMT secara angsur.

\footnotetext{
${ }^{34}$ Ahmad Rodoni, Lembaga Keuangan Syariah..., h. 65
} 
d) Murabahah, murabahah dapat diartikan saling mendapatkan keuntungan. Akad murabahah dilakukan oleh anggota sebelum jatuh tempo pada waktu yang telah disepakati.

e) Qardhul hasan, Pembiayaan kebajikan berasal dari baitul maal dimana anggota yang menerimanya hanya membayar pokoknya dan dianjurkan untuk memberikan zakat, infaq, dan shadaqah.

f) Ijarah, Akad pembiayaan yang merupakan talangan dana untuk pengadaan barang tertentu ditambah dengan keuntungan mark up yang disepakati dengan sistem sewa tanpa diakhiri dengan kepemilikan.

g) Atta'jir, Suatu kontrak sewa yang diakhiri dengan penjualan. Dalam kontrak ini pembayaran sewa telah diperhitungkan sedemikian rupa sehngga sebagian daripadanya merupakan pembelian terhadap barang secara berangsur. ${ }^{35}$

Produk-produk tersebut merupakan kegiatan-kegiatan BMT yang berkaitan langsung dengan masalah keuangan. BMT juga bisa mengembangkan usaha-usahanya yang lain dengan memperkenalkan teknologi maju untuk peningkatan produktivitas hasil usaha para nasabah, mendorong tumbuhnya industry rumah tangga atau pengelolahan hasil yang menguntungkan dalam jangka panjang dan tidak mengganggu program jangka pendek.

\section{Penutup}

Strategi promosi merupakan salah satu awal dalam rangka mengenalkan produk kepada konsumen dan ini menjadi sangat penting karena berhubungan dengan keuntungan-keuntungan yang akan diperoleh oleh perusahan. Dalam era modern ini lembaga BMT semakin berkembang di masyarakat. Perkembangan lembaga tersebut mendorong usaha BMT makin berkembang dan mengakibatkan persaingan bisnis ini menjadi ketat. Untuk itu perlu adanya strategi promosi KJKS BMT Jati Baru ini dalam menghadapi persaingan sehingga dapat membantu memasarkan produk untuk meningkatkan penjualan perusahan atau perkembangan nasabah. Adapun strategi promosi yang digunakan KJKS BMT Jati Baru dalam memasarkan produk, yaitu melalui periklanan (Advertising), penjualan perorangan

\footnotetext{
${ }^{35}$ Ahmad Rodoni, Lembaga Keuangan Syariah..., h. 67
} 
252 HIKMAH, Volume 12 Nomor 2, Desember 2018, h. 234-253

(Personal Selling), promosi penjualan (Sales Promotion), dan publisitas (Publicity). 


\section{Daftar Pustaka}

Alma. Buchari, Manajemen Pemasaran dan Pemasaran Jasa, Bandung: Penerbit Alfabeta, 2011

Craven, David W, Pemasaran Strategis, Jakarta: PT Gelora Aksara Pratama, 1996

Hakim, Arman, Nasution dkk, Manajemen Pemasaran untuk Engineering., Yogyakarta: CV Andi Offset, 2006

Hermawan, Agus, komunikasi pemasaran, Malang: PT. Gelora Aksara Pratama, 2012

Iska, Syukri dan Rizal, Lembaga Keuangan Syari'ah, Batusangkar : Batusangkar Press, 2005

Kasmir, Manajemen Perbankan, Jakarta: PT Raja Grafindo Persada, 2010

Kotler, Philip, Manajemen Pemasaran, Jakarta: Erlangga, 2008 , Dasar-Dasar Pemasaran, Jakarta: PT Midas Surya Grafindo, 1987

Lubis. Suhrawardi, Hukum ekonomi Islam, Jakarta : Sinar Grafika, 2012

Madura, Jeff, Pengantar Bisnis, Jakarta : Salemba Empat, 2007

Morrisan, Periklanan Komunikasi Pemasaran Terpadu, Jakarta:Kencana Prenada Media Group, 2010

Mursid, M., Manajemen Pemasaran, Jakarta: PT Bumi Aksara, 2014

Purnama, C.M Lingga, Strategic Marketing Plan, Jakarta: Gramedia Pustaka Utama, 2001

Rodoni, Ahmad, Lembaga Keuangan Syariah, Jakarta: PT. Bestari Buana Murni, 2008

Soemitra. Andi, Bank dan Lembaga Keuangan Syariah, Jakarta: Kencana Prenada Media Group, 2009

Swastha, Basu dan Irwan, Manajemen Pemasaran Modern, Yogyakarta : Liberty, 2005

Tjiptono, Fandy, Pemasaran Jasa dan Kualitas Pelayanan, Malang: Bayumedia Publishing, 2007

W Boyd, Harper, Manajemen Pemasaran, suatu Pendekatan Strategis dengan Orienatsi Global, Jakarta: Erlangga, 2000. 